\title{
Dialogic Communication During Covid-19 Pandemic: An Analysis on Technoparks' Social Media Usage in Turkey
}

\section{Covid-19 Salgını Sürecinde Diyalojik Illetişim: Türkiye'deki Teknoparkların Sosyal Medya Kullanımı Üzerine Bir Analiz.}

\author{
Hediye AYDOĞAN ${ }^{1} \odot$
}

Res. Asst., Akdeniz University, Faculty of Communication, Department of Advertising, Antalya, Turkey

ORCID: H.A. 0000-0001-9696-8742

Corresponding author/Sorumlu yazar: Hediye Aydoğan, Akdeniz Üniversitesi, Illetişim

Fakültesi, Antalya, Türkiye

E-mail/E-posta:

hediyeaydogan90@gmail.com

Received/Geliş tarihi: 16.12 .2020 Revision Requested/Revizyon talebi: 23.12.2020 Last revision received/Son revizyon teslimi: 17.05.2021

Accepted/Kabul tarihi: 24.05.2021

Citation: Aydoğan, H. (2021). Dialogic communication during covid-19 pandemic: An analysis on technoparks' social media usage in Turkey. Connectist: Istanbul University Journal of Communication Sciences, 60, 1-26. https://doi.org/10.26650/CONNECTIST2021-000126

\begin{abstract}
With the outbreak of the Covid-19 pandemic, social media has promptly become an essential communication tool for institutions and organizations to generate and disseminate information as well as building effective dialogue with the public. In this regard, it was vital for technoparks like many other organizations to effectively manage their social media accounts in order to inform and communicate with their stakeholders. Therefore, the current study aims to investigate how technoparks in Turkey used their social media platforms (Facebook, Twitter, and Instagram) during the first three months of the Covid-19 pandemic to facilitate dialogic communication with stakeholders, and to present the quality index of technoparks in terms of dialogic communication in social media management. In line with this aim, a content analysis of social media profiles maintained by 70 active technoparks examines the use of dialogic features originally developed in Dialogic Communication Theory. Results indicate that technoparks could not fully utilize the dialogic features of the social media platforms and that they mostly preferred to manage their social media platforms to disseminate information, which means they were away from dialogue. Recommendations are made for future studies and practitioners in terms of dialogic communication in social media management.
\end{abstract}

Keywords: Technopark, dialogic communication, social media, Covid-19, content analysis 
ÖZ

Covid-19 salgınının patlak vermesi ile birlikte, kurum ve organizasyonların bilgi üretip yaymaları ve kamularıla iletişim kurmaları açısından sosyal medya hızlı bir şekilde elzem bir iletişim aracı olmuştur. Bu bağlamda, diğer pek çok organizasyon gibi teknoparkların da paydaşlarını bilgilendirmek ve onlarla iletişim kurmak amacıyla sosyal medya hesaplarını etkili bir şekilde kullanması önem kazanmıştır. Buradan hareketle, bu araştırma, Covid-19 salgınının ilk üç aylık (çeyrek) dönemde Türkiye'de faaliyet gösteren teknoparkların hedef kitleleriyle sosyal medya hesaplarında nasıl bir iletişim biçimi sergilediğini ve diyalojik iletişim odaklı sosyal medya yönetimi açısından teknoparkların sosyal medya hesaplarının kalite endeksini ortaya koymayı amaç edinmiştir. Bu amaç doğrultusunda,
Türkiye'de faaliyet gösteren aktif 70 teknoparkın sosyal medya hesabı (Facebook, Twitter ve Instagram), esasen Diyalojik İletişim Kuramı'na dayanan diyalojik unsurlar dikkate alınarak içerik çözümlemesi yoluyla incelenmiştir. Analiz sonucunda elde edilen veriler göstermiştir ki, teknoparklar diyalojik unsurlardan yeterince başarılı olacak şekilde faydalanmamış ve sosyal medya hesaplarını bu salgın döneminde sadece bilgi yaymak amacıyla, hedef kitleleri ile diyalog kurmaktan uzak bir şekilde yönetmiştir. Araştırmadan elde edilen bulgular göz önüne alınarak gelecek çalışmalar ve uygulayıcılar için diyalojik iletişim odaklı sosyal medya yönetimi konusunda önerilerde bulunulmuştur.

Anahtar Kelimeler: Teknopark, diyalojik iletişim, sosyal medya, Covid-19, içerik çözümlemesi

\section{INTRODUCTION}

Since innovative thinking and technologies are claimed to be a fundamental sign of countries' competitiveness (Kandemir \& Illter, 2019; Cansız \& Tekneci, 2018), their economic (Chen, Ji, \& Men, 2017; Erbay \& Arkan, 2019) and technological growth in the modern world, establishing strong cooperation between universities and industries is regarded as one of the most significant actions for both developing and developed countries to boost their economic, technological, and competitive performances in the international arena by stimulating innovation (Kandemir \& Illter, 2019). One idea considered to be uniquely essential for meeting the technological needs of the industries and for fighting against the immense poverty in developed countries after World War II was that of creating significant cooperation between universities and industries, or the 'technopark'.

The concept dates back to the 1950s with the initiation of the first world-renowned technopark named 'Silicon Valley' in the United States of America, where many global companies like Google, Intel, and Yahoo maintain their operations. Furthermore, it is stated that Silicon Valley emerged as a result of the great diligence of a group of researchers at Stanford University (Kandemir \& IIlter, 2019), who were willing to commercialize their innovative research in order to turn their technological and R\&D knowledge into economic value. Realizing the effectiveness of technoparks for countries to develop several significant projects with tremendous impact on the international arena (Erbay \& Arkan, 2019), Turkey as a dynamic and developing country first introduced 
'Technology Development Centers' two decades later in 1990, and then put into force the Technology Development Zones (Technoparks) Law number 4691 in 2001 (Cansız \& Tekneci, 2018), which defines 'technoparks' as organized research and business development ecosystems where universities/research institutes and industry firms come together to manage profitable and rewarding research, development, and innovative projects, where they share a great amount of knowledge and technological transfers among themselves, and where the academic, economic, and social structures coalesce with each other (Kandemir \& IIter, 2019, p. 1218). Regarding technoparks as public ventures for R\&D projects (Erbay \& Arkan, 2019), this Law stipulated three main objectives, namely to transfer grand knowledge accumulation of universities to several types of developing and developed industries, to provide substantial funds for firms, and to create tremendous synergy by bringing together the operating firms with similar missions in technoparks established through the active participation of administrators from universities, industries, government, and local authority (Kandemir \& Ilter, 2019). Within the scope of these objectives, there are many other reasons for the establishment of technoparks to make use of their benefits in turn. Technoparks are established with the aim of increasing the standards and quality levels of products, enriching technological knowledge, enabling the adaptation of small and medium sized firms to said higher technology, increasing foreign investments into the high technology projects, providing researchers with new kinds of career options (Sanayi ve Teknoloji Bakanlığı, 2020), increasing the level of education and employment in the region (Erbay \& Arkan, 2019), supporting entrepreneurship in innovative areas (Kandemir \& illter, 2019; Türkeli \& Boyacı, 2019), directing private sector firms to develop technology-based R\&D projects in many scientific and technological fields such as software development (Kandemir \& Ilter, 2019; Erbay \& Arkan, 2019), and enhancing the competitive advantage of the industry (Cansız \& Tekneci, 2018; Sanayi ve Teknoloji Bakanlığı, 2020). Technoparks might make contributions of the utmost importance to the economy of countries even through attracting foreign investors to projects, which can be achieved with the effective use of social media. Therefore, it has been considered vital during the Covid-19 process to provide high-quality products integrated with technological knowledge (Hahn \& McMeekin, 2020) and new employment opportunities against the increasing rate of unemployment in Turkey and across the globe (Açıkgöz \& Günay, 2020). With that in mind, it can be managed, by assisting the entrepreneurs and private firms from innovative and productive sectors, to stand against the unfavorable outcomes of Covid-19.

Technoparks as dynamically powerful technology development zones (Sanayi ve Teknoloji Bakanlığı, 2020) hosting established firms in Turkey (Cansız \& Tekneci, 2018) 
mainly have the utmost aim of developing and implementing R\&D projects designed specifically by the collaboration of universities and research centers. Thus, they are expected to communicate and share knowledge with their stakeholders in order to develop new ideas and projects (Kandemir \& Ilter, 2019) contributing to countries, firms, and academics. In this regard, it is of great importance for them to maintain these communicative and knowledge-sharing practices in a more dialogic manner in the digital world, as it is also claimed by Türkeli and Boyacı (2019) in their study that communication with external stakeholders at technoparks shows great levels of failure, which needs to be replaced with immediate improvements and achievements.

As a medium of establishing an influential relationship between not only industries and universities, but also many other actors such as the technopark firms, ministries, suppliers, clients, media, and public in general, technoparks heavily rely on communication, which has changed strikingly with the advent of Web 2.0 (Arslan, 2019). This makes it possible for users to find opportunities to develop dialogue with whomever they want to contact through social media platforms like Facebook, Twitter, and Instagram, unlike Web 1.0, which only created an environment for monologue. As Kent (2017) indicates, unlike dialogue "based on positive regard, mutuality, empathy, propinquity, trust and commitment" (p. 111), creating open, experiential, and rule-dependent conversation and interaction, monologue refers to "one-way, self-serving, propagandistic, risk-free, manipulative and exploitative" (p. 111) communication. In this context, Grunig and Hunt (1984) explain that the monologue-oriented public relations (PR) activities only serve for the dissemination of information without the need of feedback from the receivers of messages to strengthen communication. They call these kind of PR activities "one-way PR" while they state that the ideal kind of activities are the "two-way PR", in which senders and receivers of the PR messages exchange information with each other in a dialogic manner. It is claimed that the latter results in a win-win situation for parties on both sides of the conversation. Similarly, Heath and Bowen (2002) associate organization managing monologue-oriented PR activities with "a failing society that cannot accommodate to robust dialogue" (p. 237). To transform from a failing society into an upstanding society, Web 2.0 is regarded as a profound opportunity that organizations can use for their PR activities to build favorable communication with stakeholders. In this regard, Breakenridge (2008) defines "PR 2.0" as PR which uses Web 2.0 platforms and applications.. Later in her follow-up book co-authored with Solis, she asserts that PR 2.0 puts "the public back in public relations", because, in PR 2.0, "monologue has given way to dialogue" (Solis, 2011, p. 2), which mainly creates and is created by profound interaction. 
In the modern technology-driven society, the interaction between organizations and stakeholders in terms of PR can be achieved through Web 2.0 (Oltarzhevskyi, Kliuchnykova, Sokolova, \& Tsymbalenko, 2018; Silkü-Bilgilier \& Kocaömer, 2020; Aslan, 2017; Shin, Pang, \& Kim, 2015; Kim, Chun, Kwak, \& Nam, 2014a). Similarly, as Pang and fellows (2018) put forth, it is integrated into daily life, where new and extant relationships can be created and reinforced effectively through the use of social media platforms as an emergent medium for a more direct, reciprocal, and dialogic way of communication (Kim, Kim, \& Nam, 2014b; Sundstorm \& Levenshus, 2015; Yağmurlu, 2013; Capriotti \& Losada-Díaz, 2018; Wang \& Yang, 2020; Taylor \& Kent, 2014). Dialogic communication as a key term of the Dialogic Communication Theory initially introduced by Kent and Taylor (1998) refers to "any negotiated exchange of ideas and opinions" (p. 325), and requires any social media platform to conform to five principles in order for them to generate interaction and relationships between the senders and receivers of the messages. According to the Dialogic Communication Theory (Kent \& Taylor, 1998; Taylor, Kent, \& White, 2001; Kent \& Taylor, 2002; Taylor \& Kent, 2014), these five principles, namely'ease of interface,',usefulness of information','conservation of visitors,',generation of return visits', and 'dialogic loop', can be organized into mainly two clusters: technical/ design cluster and dialogic cluster (Taylor et al., 2001). It was stated that while the technical/design cluster includes the principles of usefulness of information, ease of interface, and conservation of visitors, the dialogic cluster consists of the principles of generation of return visits and dialogic loop (Taylor et al., 2001). The principle of usefulness of information refers to the appropriate and relevant information available online for the needs of receivers, while the principle of ease of interface takes into account the performance of the platforms for navigation, and the principle of conservation of visitors means the actions taken to keep the visitors on the social media platforms throughout their visits (Yue, Thelen, Robinson, \& Men, 2019; Men, Tsai, Chen, \& Ji, 2018). In the dialogic cluster, the principle of generation of return visits refers to the existence of features that attract visitors to regularly come back to the social media accounts, while the principle of dialogic loop means that social media accounts efficiently function through feedback and exchange of information between senders and receivers of the social media messages (Yue et al., 2019). According to Taylor and colleagues (2001), the principles in the technical/design cluster are the preliminary steps for dialogue to come into existence, whereas those in the dialogic cluster are vital to generate real dialogic communication. This means that all principles work in harmony for dialogic communication to emerge online, and any organization attempting to build strong relationships and dialogue with its stakeholders should avoid skipping any of these 
principles, although it ought to be taken into consideration that not every platform online includes all features congruent with these principles. In this sense, the features of the principle of ease of interface are not applicable to the analysis of social media platforms such as Facebook, Twitter, and Instagram in terms of dialogic communication.

As one of the leading social networking platforms, Facebook offers its users to share information, create and sustain constant interaction (such as conversation, negotiation, discussion, exchange, and so on), and cultivate dynamic relationships with their key audiences, which in turn gives way to developing strong dialogue, through its powerful dialogic functions (Capriotti \& Losada-Díaz, 2018) such as comments, reactions, polls, and events and the like. Unlike some prior research (Kim et al., 2014b), more recent studies (Haro-de-Rosario, Sáez-Martín, \& del Mar Gálvez-Rodríguez, 2017; Saxton \& Waters, 2014; Capriotti \& Losada-Díaz, 2018; Oltarzhevskyi et al., 2018; Shin et al., 2015) assert that many organizations manage their Facebook accounts only for disseminating information instead of establishing a two-way dialogue.

Twitter, which is a microblogging site that allows its users to communicate with each other and express their opinions regarding anything from their private life to current situations in 280 characters on a real-time basis (Sundstorm \& Levenshus, 2015; Linvill, McGee, \& Hicks, 2012; del Mar Gálvez-Rodríguez, Caba-Pérez, \& López-Godoy, 2016), can be utilized to create interactivity, credibility and dialogic communication with their followers and stakeholders through its tools (Rybalko \& Seltzer, 2010; Sundstorm \& Levenshus, 2015) such as hashtags, mentions, and polls. Many organizations subject to the previous research in the academic literature (unlike a few studies like Sundstorm \& Levenshus in 2015) were found to manage their Twitter accounts in a way compatible with the principle of conservation of visitors (Rybalko \& Seltzer, 2010; Kemna, 2013; del Mar Gálvez-Rodríguez et al., 2016; Beverly, 2013; Shin et al., 2015; Yue et al., 2019). In their study regarding the Twitter management of non-profit and forprofit organizations in terms of dialogic communication, Wang and Yang (2020) found out that while the principles of usefulness of information, conservation of visitors, and generation of return visits were the most applied dialogic communication principles by the non-profit organizations, for-profit organizations managed their Twitter accounts mostly in conformity with the principle of dialogic loop. According to the authors, one possible reason behind this was that they saw Twitter as a free platform to reach their audiences mainly for disseminating information (Wang \& Yang, 2020, p. 6), just like a news agency for their organizations. 
When Instagram as a social media platform specifically based on visuality is taken into consideration in terms of dialogic communication, it is found that this social media platform allows its users to manage their relationships and interactions with their 'followers' in a more dialogic way by reducing the unidirectionality and increasing the participation of the users through its features (Silkü-Bilgilier \& Kocaömer, 2020; Arslan, 2019) such as comments, mentions, and story features (polls, ask me a question, emoji slider, etc.). The few studies (Silkü-Bilgilier \& Kocaömer, 2020; Arslan, 2019) carried out in the Turkish literature on the usage of Instagram accounts in terms of dialogic communication principles found that organizations failed to manage this, which highlights that they were unable to take full advantage of Instagram's dialogic features. When considered as a whole, these three social media platforms were recognized as a beneficial and effective tool for start-up companies carrying out operations for R\&D, product innovation, and technological development to build potent dialogue with stakeholders including employees, customers, and investors as well as to reinforce the companies' sales, revenues, generate awareness, receive free publicity, and to attain organizational legitimacy and promotion (Men, Ji, \& Chen, 2017).

It is alleged that PR activities using social media platforms as a cost-effective medium (Chen et al., 2017) to create dialogic communication build not only interaction and relationship (Kent \& Taylor, 2002), but trust (Yağmurlu, 2013, p. 99), strong corporate identity (Chen et al., 2017, p. 244), opinion leadership (Capriotti \& Losada-Díaz, 2018, p. 649), and a reputable image (Pang et al., 2018, p. 70). However, it is of great importance to note here that the studies (Pang et al., 2018; McAllister-Spooner, 2009; Seltzer \& Mitrook, 2007; Arslan, 2019; del Mar Gálvez-Rodríguez et al., 2016; Saxton \& Waters, 2014; Silkü-Bilgilier \& Kocaömer, 2020; Linvill et al., 2012; Wang \& Yang, 2020; Rybalko $\&$ Seltzer, 2010) have indicated that numerous organizations are far away from making use of these advantages and opportunities, which results in mostly monologue on social media platforms which function like a"failing society that cannot accommodate to robust dialogue" (Heath \& Bowen, 2002, p. 237). This sparks the question of how technoparks as one of the key organizations in Turkey have used their social media platforms especially during the first three months of the Covid-19 pandemic, when people actively spent most of their 'stay-at-home' time on social media for various purposes.

With the onset of the Covid-19 pandemic throughout the world in the early days of the year 2020, people have had to change their routines in their daily and work life 
by staying at home (Hussein \& Aljamili, 2020) for lockdown and quarantine reasons in order to prevent the spread of the easily contagious virus. This has led them to spend most of their time on online platforms for an instant and easy connection (GonzálezPadilla \& Tortolero-Blanco, 2020; Silahtaroğlu, Baykal, \& Canbolat, 2020; Katz, Callorda, \& Jung, 2020; Socialbakers.com, 2020; Banga \&Willem te Velde, 2020) with their families and friends as well as their colleagues and clients. Within this period, social media and other internet technologies developing per second have become much more significant than ever before (Uluslararası Dijital Medya ve Illetişim Derneği, 2020; Cukurova Expres, 2020; Nielsen, Fletcher, Kalogeropoulos, \& Simon, 2020) for institutions, organizations, and brands as a tool to engage with their stakeholders easily (Socialbakers.com, 2020).

Especially in Turkey, where 54 million people actively use social media platforms on a daily basis according to Digital 2020: Turkey report (We Are Social \& Hootsuite, 2020), it has been put forth that social isolation and home-office working conditions (Paril, 2020; Silahtaroğlu et al., 2020) practiced for precautionary measures against the spread of the pandemic have caused 61 percent of their users to spend more time on social media channels in the first three months of the Covid-19 pandemic (Cukurova Expres, 2020; Uluslararası Dijital Medya ve Illetişim Derneği, 2020). In this context, it gains importance to answer the question of how technoparks as organizations with the aim of generating and commercializing technological knowledge used their social media platforms (Instagram, Facebook, and Twitter) in order to create strong and highquality engagement by building effective dialogic communication with their stakeholders in the first three months of the Covid-19 pandemic in Turkey. The time period considered within the scope of this study starts from March, when the first case of Covid-19 was officially reported in Turkey, and strict restrictions were implemented such as lockdowns, curfews, quarantine, and social distancing, and ends in June, when the normalization period for people in Turkey started and people could spend time out of home on condition that they obeyed the rules for going-out.

Being the first research analyzing the social media use of technoparks in Turkey in terms of dialogic communication principles, this study differs from previous ones on several counts. While prior research examined either only Facebook (Capriotti \& LosadaDíaz, 2018; Haro-de-Rosario, Sáez-Martín, \& del Mar Gálvez-Rodríguez, 2017; Saxton \& Waters, 2014), Twitter (del Mar Gálvez-Rodríguez et al., 2016; Kemna, 2013; Linvill et al., 2012; Rybalko \& Seltzer, 2010; Sáez Martín, de Rosario, \& Caba Pérez, 2015; Sundstorm \& Levenshus, 2015; Wang \& Yang, 2020; Yue et al., 2019), and Instagram (Arslan, 2019; 
Silkü-Bilgilier \& Kocaömer, 2020), or only two of these social media platforms (Kim et al., 2014a; Kim et al., 2014b; Shin et al., 2015; Yağmurlu, 2013), this study takes a more holistic approach and conducts content analyses of these three social media platforms in terms of the dialogic communication principles. In addition, to the best knowledge of the authors, this study holds the title of being the first research which attempts to present the quality indexes [an index based on the determinants of the quality of the social media platforms to determine their excellence in terms of dialogic communication, as stated by Navarro-Ruiz and Humanes Humanes (2012)] of these social media platforms regarding their adoption of the dialogic communication principles in order to reveal the strengths and weaknesses of each social media platform of technoparks, and to make suggestions for dialogic communication management.

\section{AIM AND METHODOLOGY}

The scholarly literature on public relations and Dialogic Communication Theory presented in this study revealed that the social media management of companies, brands, institutions and organizations for the purposes of public relations activities can help them build effective dialogic communication with their stakeholders, when they adopt the dialogic communication principles in their social media platforms. While the prior scholarly works centered mostly on the analysis of only one social media platform of companies or organizations in terms of dialogic communication principles, this study examines the technoparks' three social media platforms ranked among the five most-used social media platforms in Turkey (We Are Social \& Hootsuite, 2020, p. 43) and compares them with each other in regards to the dialogic communication principles during the first three months of the Covid-19 pandemic in Turkey. Furthermore, this study makes an original contribution to the academic literature, by bringing forward whether these technoparks can be considered to have social media platforms of high quality, considering the quality indexes determined for social media platforms individually and collectively.

\section{Aim}

Previous studies, especially the findings of the Men et al.'s 2017 and Chen et al.'s 2017 studies, motivated the author to analyze the dialogic characteristics of the social media accounts of technoparks, particularly during the first three months of the Covid-19 pandemic in Turkey. This study examines the social media platforms of the active 
technoparks in Turkey, since studies within Turkey and across the globe pointed out that, with the outbreak of the Covid-19 pandemic, people started to spend more time on the Internet, especially on social media platforms (Banga \& Willem te Velde, 2020; Nielsen et al., 2020; Cukurova Expres, 2020), in the first three months of the pandemic (Silahtaroğlu et al., 2020)

- as a form of escapism from high levels of fear and anxiety resulting from said pandemic (Hussein \& Aljamili, 2020; Katz et al., 2020),

- to keep updated with the news around the globe (Uluslararası Dijital Medya ve İletişim Derneği, 2020),

- to search for health-related issues (Katz et al., 2020),

- to perform their work (Banga \&Willem te Velde, 2020; Hussein \& Aljamili, 2020), and

- to ameliorate the social isolation (Hussein \& Aljamili, 2020; González-Padilla \& Tortolero-Blanco, 2020) stemming from the lockdown, quarantine periods, and social distancing (Silahtaroğlu et al., 2020; Banga \& Willem te Velde, 2020), which spurred on the closing of places used for socialization, education and consumption such as schools, cafés, pubs, shops, and offices, and so on (Katz et al., 2020) and even the cancellations of travelling, celebrations, occasions for sharing condolences, and holidays, and so on (Banga \& Willem te Velde, 2020).

Throughout the first three months of the Covid-19 period when people were in need of fulfilling the needs aforementioned, Paril (2020) stated that social media platforms such as Facebook and Twitter rushed to satisfy those needs, and therefore experienced double-digit increases in daily active users. This highlights the importance of these social media platforms in the lives of people struggling to maintain their daily private and work lives despite complicated challenges for those people originating from the Covid-19 pandemic.

As Turkey was the main focus of this study, the research was carried out for the determination of the digital and social media use. It brought into view that the social media consumption of the Turkish people during the first three months of Covid-19 in Turkey (covering the months March, April, and May) - the time period when restrictions such as lockdown and quarantine were in place until the normalization process, which began on June 1, 2020 (Silahtaroğlu et al., 2020) - showed a significant increase. It was conceived as a result of the fact that people found their 'new normal' life in the social media (or virtual) world, as Arslantürk (Cukurova Expres, 2020) stated in her article. 
With the first contracted case of Covid-19 officially announced in Turkey on March 11, 2020, several measures and restrictions were introduced, as chronologically listed in Wikipedia (2020), like the closing of bars and nightclubs (as of March 15), schools (as of March 16), universities (as of March 26), public gathering places like cafés, gyms, mosques and movie theaters (as of March 16), barber shops, beauty parlours, restaurants, and parks for barbecuing and gathering (as of March 21), a curfew for people aged 65 and above or for the chronically ill (as of March 21), the 'stay-at-home' calls by the President (as of March 18), and the bans on physical exercise outside, overseas flights (as of March 27), and intercity travelling without a travel permit (as of March 28) were implemented by the Turkish government, getting stricter by the day, until June 1 - nearly three months after the first case was officially reported - when the Turkish public was allowed to maintain a life outside of the home with less restrictions, but still adhering to obligations such as social distancing, mask-wearing and hygiene. This was considered the awaited resumption of the normal life referred to as the 'new normal' (Durmuş, 2020; Bulut, 2020). Since Wold (2020) asserted in her study that people headed to the Internet en masse and had an increasing level of social media consumption, especially on Instagram (Wold, 2020), and because in Turkey, it was found out in a survey (Uluslararası Dijital Medya ve lletişim Derneği, 2020) that more than half of the respondents increased the level of their social media use during the days when strict measures like lockdown, social distancing, and quarantine were at their height, it is of utmost importance to find out how technoparks in Turkey managed their social media accounts with regard to the dialogic communication principles in order to build strong dialogue for the primary purpose of fulfilling their aims during this period.

While choosing the social media platforms to be addressed in this study, the Digital 2020: Turkey report (We Are Social \& Hootsuite, 2020, p. 43) was taken into consideration, according to which Instagram ranked second after YouTube in the most used social media platforms list with users equal to 83 percent of the total population in Turkey, followed by Facebook (76\%) and Twitter (61\%). In this regard, the following research questions are offered:

RQ1: What types of social media were frequently adopted by technoparks during the first three months of the Covid-19 pandemic?

RQ2: Which principle(s) of dialogic communication were employed by technoparks on their: 
RQ2a: Instagram accounts?

RQ2b: Facebook accounts?

RQ2c: Twitter accounts?

RQ3:What is the quality index of each social media platform of technoparks in terms of the principles of dialogic communication?

\section{Methodology}

In order to answer the research questions, a content analysis of the social media accounts of technoparks was conducted on SPSS 23.00 version, since content analysis in communication-related researches makes it possible for researchers to make systematic, objective and quantitative evaluations, and valid and replicable inferences of the data obtained (Berelson, 1952; Yıldırım \& Şimşek, 2018; Krippendorf, 2004). The criteria for the social media accounts to be taken into consideration for analysis were that the technoparks were specified as'active' by the Ministry of Industry and Technology of Turkish Republic (Sanayi ve Teknoloji Bakanlığı, 2020), and that they shared several posts and tweets during the first three months of the Covid-19 pandemic. Among 70 technoparks, only 49 (Active: 44; Passive: 5) were identified as having an Instagram account, 55 (Active: 43; Passive: 12) as having a Facebook account, and 59 (Active: 53; Passive: 6) as having a Twitter account. Furthermore, although it is not the scope of this study to analyze other social media accounts of technoparks in terms of dialogic communication principles, it is of importance to note here that it was found out that only 35 technoparks had active Linkedln pages and 26 technoparks had active YouTube pages when their YouTube and Linkedln pages were taken into account.

All accounts within the framework of this study were accessed on a daily basis between March - June 13,2020, and analyzed comprehensively through a code sheet developed for this study by two experienced coders. The intercoder reliability was assessed using Scott's pi (1955), which resulted in reliability coefficients ranging from 0.90 to 0.94 . This indicated that a strong level of intercoder reliability existed. To address $\mathrm{RQ} 3$, the mean value of each principle for each social media platform was taken into account. In the coding phase, the features on each social media platform regarding the availability of the dialogic communication principles were coded as either present (1) or absent (0). In this case, each platform analyzed was able to obtain a score from 0 to the number of items listed in the code sheet (55 for Instagram, 27 for Facebook, and 38 for Twitter), then we decided to regard the variables on a scale of 0 to 1 , and 
obtained the mean value for each platform. Therefore, each platform was at a point on the quality index (0-1) according to the mean value, and the mean value indicated what percent of the quality criteria was met. For example, if a platform obtained the mean value of 0.496 , then it meant that $49.6 \%$ of the quality criteria was met. In the next phase, each variable listed as one of the items of each dialogic communication principle was computed into a new variable according to the mean, and then the total mean value of new variables referring to each principle was considered for each platform in order to calculate the quality index.

The code sheet (see Table 1) was developed with adaptations from previous studies [(for Instagram: Silkü-Bilgilier \& Kocaömer, 2020; Arslan, 2019), (for Facebook: Kim et al., 2014a; Yağmurlu, 2013; Shin et al., 2015), (for Twitter: Kim et al., 2014a; Sáez Martín et al., 2015; Yue et al., 2019; Wang \& Yang, 2020; Yağmurlu, 2013; Shin et al., 2015)] focusing on dialogic communication principles for each social media platform addressed in this study, and new features of each social media platform missing in the previous studies were added as an item to the code sheet. Since the social media platforms addressed in this study do not contain any features necessary for the inclusion of the principle of ease of interface, this principle was taken out of the analysis.

\section{FINDINGS}

In this study, three research questions were addressed and answered with the help of content analysis. In this regard, RQ1 explored the frequently used social media platforms of technoparks during the first three months of the Covid-19 pandemic in Turkey in order to find out which social media platform was preferred the most by technoparks. The descriptive tests utilized to answer this question showed that among the social media platforms adopted by the technoparks, the adoption rate for Twitter was the highest $(n=53,75,7 \%)$, followed by Instagram $(n=44,62,8 \%)$ and Facebook $(n=43,61,4 \%)$.

Regarding RQ2, each social media platform was analyzed to reveal their adoption of the principles of dialogic communication. As a result of the analyses conducted, indices calculated for each of the dialogic principles on Instagram accounts as an answer to RQ2a indicated that features related to the principle of 'usefulness of information' were the most frequently applied feature $(M=56.11, S D=17.65)$, followed by the principle of 'generation of return visits' ( $M=47.92, S D=22.81)$, the principle of 'conservation of visitors' $(M=44.81, S D=20.4)$ and the 'principle of dialogic loop' $(M=18.51, S D=8.89)$. 
The indices calculated for Facebook accounts as an answer to RQ2b showed that the features related to the principle of 'generation of return visits' were mostly applied $(M=55.35, S D=26.84)$, followed by the principle of 'conservation of visitors' $(M=54.26$, $S D=23.02)$, the principle of 'usefulness of information' $(M=48.06, S D=19.82)$, and the principle of 'dialogic loop' $(M=17.94, S D=12.5)$. As an answer to $R Q 2 c$, the indices calculated for Twitter accounts pointed to the fact that the principle of 'conservation of visitors' was most frequently employed ( $M=64.15, S D=51.41)$, followed by the principle of 'generation of return visits' $(M=53.67, S D=20.99)$, the principle of 'usefulness of information' (M=49.16, SD=14.38), and the principle of'dialogic loop' $(M=31.45, S D=22.4)$.

To answer RQ3, which was asked to discover the quality indexes of social media platforms of technoparks in terms of the principles of dialogic communication, the total mean value of the principles of dialogic communication for each social media platform was calculated. While Figure 1 shows the quality indexes of each social media platform, Figure 2 represents the quality indexes of each social media platform for each principle of dialogic communication.

\section{DISCUSSION AND CONCLUSION}

The primary purpose of this study was to determine how technoparks managed their social media accounts (Facebook, Instagram, and Twitter) in terms of the principles of dialogic communication during the first three months of the Covid-19 pandemic. Accordingly, this study carried out a content analysis of the social media platforms of 70 active technoparks as listed by the Turkish Republic Ministry of Industry and Technology in regard to their employment of the principles of dialogic communication.

First of all, it should be noted that nearly three-fourths of all technoparks (72\%) showed presence on the social media platforms, and Twitter was the most utilized social media platform adopted by the technoparks. There were some interesting findings about social media platforms of technoparks: 1) Although there are some websites of technoparks that include no links or invalid links to social media platforms, searches on social media platforms present official accounts; 2) Some technoparks prefer to manage Facebook accounts that can be added as a friend instead of using Facebook's page feature; 3) One technopark (titled 'Muallimköy TDZ') created social media accounts with the name of 'bilisimvadisi' linked by the website; and 4) Most of the social media posts are synchronously shared on all three platforms without taking into consideration their different requirements and features. 
Given the fact that Instagram came before Twitter on the list of most popular social media platforms in Turkey (We Are Social \& Hootsuite, 2020), our study reported that Twitter was the most preferred platform by technoparks, followed by Instagram and Facebook respectively. This finding indicates that technoparks did not pay attention to the statistics regarding the popularity of social media platforms in Turkey when they chose which platform they would use to reach their stakeholders, which may be because they simply assumed that their stakeholders use Twitter more than the other two platforms.

The findings regarding the employment of the principles of dialogic communication present many insights regarding the social media management of technoparks. Above all, consistent with the previous studies (Sundstorm \& Levenshus, 2015; Linvill et al., 2012; del Mar Gálvez-Rodríguez et al., 2016; Pang et al., 2018; McAllister-Spooner, 2009; Seltzer \& Mitrook, 2007; Chen et al., 2017; Men et al., 2017), technoparks performed low on all three social media platforms in the employment of the principle of dialogic loop. Moreover, the findings of this study revealed that Twitter accounts of technoparks scored better than Facebook and Instagram regarding the technical/design cluster (which includes usefulness of information and conservation of visitors), and regarding the dialogic cluster (which includes dialogic loop and generation of return visits). They showed some similarities with the findings of the study by Oltarzhevskyi and colleagues (2018) and that of Sundstorm and Levenshus (2015), who set forth that Twitter is actively used by brands and organizations, especially for building dialogic communication with stakeholders. Overall, this suggests that technoparks were far from managing their social media accounts in a dialogic manner. Besides, it is concluded that they did not make use of the advantages of social media platforms to build stronger dialogues with their stakeholders particularly during the pandemic days when most of their stakeholders were expected to stay home, work from home and also to search for new entrepreneurship, research and development opportunities which technoparks could offer. As for each principle of dialogic communication, it is clear that Instagram accounts were preferred mostly for disseminating information (as also found in the studies of Silkü-Bilgilier and Kocaömer in 2020, and Arslan in 2019), while Facebook accounts were used mostly for attracting audiences for their return visits (which results in deficiency in dialogic communication as discovered by Haro-de-Rosario, Sáez-Martín, \& del Mar GálvezRodríguez, 2017; Saxton \& Waters, 2014; Capriotti \& Losada- Díaz, 2018; Oltarzhevskyi et al., 2018; Shin et al., 2015 in their studies), and the technoparks mostly used features of Twitter that made it possible to keep audiences on the platform (which shows important similarities with the major findings of prior research such as Rybalko \& Seltzer, 
2010; Kemna, 2013; del Mar Gálvez-Rodríguez et al., 2016; Beverly, 2013; Shin et al., 2015; Yue et al., 2019). This may signal the different social media strategies of technoparks for each platform, which, if that is the case, demonstrates that there is no consistency among those strategies. This may even be a result of the probability that each platform is managed by different social media managers. Considering the overall results, it can be concluded that the presence of social media accounts is viewed by the technoparks' administrators as a must-have platform, but not as a strong medium for building communication, attracting investors, and creating a reputable image, which may result in the use of social media accounts mostly for monologue rather than dialogue, in contrast to the expectations of many social media theorists that many organizations use social media as a way to put the "public" back in "public relations".

To sum up, this study concludes that the technoparks did not fully utilize the dialogic potential of the social media platforms, which were more broadly used during the first three months of the pandemic in Turkey, but they did mostly try to make use of the social media platforms as a free news space where they could inform their stakeholders about themselves generally, which resulted in the monologue-oriented management of social media platforms, regardless of the dialogic features present such as polls, hashtags, and mentions. As a result, this study suggests that technoparks need to better utilize the highly effective features of each social media platform to build dialogue with their key stakeholders through more comprehensive and consistent social media strategies specified by PR experts. The overall conclusion from the findings of this study is that technoparks fell short of dialogic management on their social media platforms, which in turn makes the platforms themselves their own "failing society" where they become devoid of the stupendous chance to build strong, effective and mutual relationships and dialogue with their followers and stakeholders, whereas they could create a successful and rising society through the use of the features and attributes of these platforms full of dialogic functions.

Even though there are several significant findings in this study, it is not free of limitations in terms of methodology since content analysis does not let the researchers deeply explore the reasons and justifications for what is found out as a result of the analysis. In line with that, this study lacks qualitative data regarding why technoparks manage their social media accounts in a more monologue-oriented manner, which can be achieved through interviews with social media managers of technoparks, and which future studies are highly recommended and encouraged to carry out in order to bring to light a deeper 
understanding regarding the opinions and views of the social media managers of technoparks. In addition to studies with qualitative research designs for delving into the reasons for why social media managers manage the Facebook, Twitter, and Instagram accounts of technoparks in Turkey in the way which was found out in this study, it is of great importance to conduct qualitative research with the target audiences of the technoparks in order to put forth how they view the social media management of technoparks in terms of dialogic communication. Thus, future studies are recommended to change the methodology and compare their results with those of this study in order to present more clear insights about the social media management of technoparks regarding the dialogic features included. They can also conduct content-analysis of the social media platforms of technoparks in other countries, especially those in Silicon Valley, and present comparative results with the findings of this research by also measuring the quality index of those platforms. Lastly, since this study focuses on the social media management of technoparks in terms of the dialogic communication principles, specifically during the first three months of the Covid-19 pandemic in Turkey, it can be suggested that future research analyze the data for a longer period of time.

Peer-review: Externally peer-reviewed.

Conflict of Interest: The author has no conflict of interest to declare.

Grant Support: The author declared that this study has received no financial support.

\section{REFERENCES}

Açıkgöz, Ö., \& Günay, A. (2020). The early impact of the covid-19 pandemic on the global and Turkish economy. Turkish Journal of Medical Sciences, 50, 520-526. DOI: 10.3906/sag-2004-6

Arslan, C. (2019). An analysis of Instagram's dialogical communication building potential in Turkish Theater Institutions. Sanat \& Tasarım Dergisi, 84-98.

Aslan, A. (2017). Web sitelerinin birer diyalojik iletişim aracı olarak kullanımı üzerine bir değerlendirme: Türkiye'deki büyükşehir belediyeleri örneği. Süleyman Demirel Üniversitesi Iktisadi ve Idari Bilimler Fakültesi Dergisi, 22, 2425-2436.

Banga, K., \& Willem te Velde, D. (2020). Covid-19 and disruption of the digital economy; evidence from low and middle-income countries. Digital Pathways Paper Series 7, Oxford, UK: Digital Pathways at Oxford.

Berelson, B. (1952). Content analysis in communication research. New York, USA: Free Press.

Beverly, J. A. (2013). Public relations models and dialogic communication in the Twitterverse: An analysis of how colleges and universities are engaging their publics through Twitter (Doctoral Dissertation). Retrieved from https://aquila.usm.edu/cgi/viewcontent.cgi?article=1180\&context=dissertations.

Breakenridge, D. (2008). PR 2.0: New media, new tools, new audiences. Upper Saddle River, NJ: FT Press, Pearson Education. 
Bulut, F. (2020, June 5). Turkey cancels initially planned weekend curfew [Web log post]. Retrieved from https:// www.aa.com.tr/en/turkey/turkey-cancels-initially-planned-weekend-curfew/1866301

Cansız, M., \& Tekneci, P. D. (2018). Innovative and technology-based women entrepreneurs in Turkey: Capital and performance. Journal of Economy Culture and Society, 57, 151-183. DOI: 10.26650/JECS372449

Capriotti, P., \& Losada-Díaz, J.-C. (2018). Facebook as a dialogic communication tool at the most visited museums of the world. El profesional de la información, 27(3), 642-650. DOI: 10.3145/epi.2018.may.17

Chen, Z. F., Ji, Y. G., \& Men, L. R. (2017). Strategic use of social media for stakeholder engagement in startup companies in China. International Journal of Strategic Communication, 11(3), 244-267. DOI: 10.1080/1553118X.2017.1298114

Cukurova Expres. (2020, July 07). Yeni Normalimiz "Sanal Dünya" [Web log post]. Retrieved from http://www. cukurovaexpres.com/ozel-haber/yeni-normalimiz-sanal-dunya-h255492.html.

del Mar Gálvez-Rodríguez, M., Caba-Pérez, C., \& López-Godoy, M. (2016). Drivers of Twitter as a strategic communication tool for non-profit organizations. Internet Research, 26(5), 1052-1071. DOI: 10.1108/IntR-072014-0188

Durmuş, Y. Z. (2020, June 1). 'New normal' begins in Turkey as most pandemic-related restrictions lifted [Web log post]. Received from https://www.dailysabah.com/turkey/new-normal-begins-in-turkey-as-mostpandemic-related-restrictions-lifted/news?gallery_image=undefined\#big

Erbay, E. R., \& Arkan, D. (2019). Teknoparkların mevcut durumu. In: D. K. Dimitrov, D. Nikoloski \& R. Yılmaz (Eds.), Prooceedings of XI. International Balkan and Near Eastern Social Sciences Congress Series (pp. 703-705), 9-10 March 2019, Tekirdağ, Turkey.

González-Padilla, D. A., \& Tortolero-Blanco, L. (2020). Social media influence in the covid-19 pandemic. International Brazilian Journal of Urology, 46(1), 120-124. DOI: 10.1590/S1677-5538.IBJU.2020.S121

Grunig, J. E., \& Hunt, T. (1984). Managing public relations. New York: Holt, Rinehart \& Winston.

Hahn, S. M., \& McMeekin, J. A. (2020, February 24). Coronavirus Update: FDA steps to ensure quality of foreign products [Web log post]. Retrieved from https://www.fda.gov/news-events/press-announcements/ coronavirus-update-fda-steps-ensure-quality-foreign-products

Haro-de-Rosario, A., Sáez-Martín, A., \& del Mar Gálvez-Rodríguez, M. (2017). Facebook as a dialogic strategic tool for European local governments. Transylvanian Review of Administrative Sciences, 50, 73-89. DOI: 10.24193/ tras.2017.0005

Heath, R. L., \& Bowen, S. A. (2002). The public relations philosophy of John W. Hill: Bricks in the foundation of issues management. Journal of Public Affairs, 2(4), 230-246. DOI: 10.1002/pa.116

Hussein, A. T., \& Aljamili, L. N. (2020). Covid-19 humor in Jordanian social media: A socio-semiotic approach. Heliyon, 6, 1-12, DOI: 10.1016/j.heliyon.2020.e05696

Kandemir, T., \& İlter, B. (2019). Girişimcilik faaliyetlerinde Teknoparkların önemi: Afyon-Uşak Zafer Teknoloji Geliştirme Bölgesi örneği. Afyon Kocatepe Üniversitesi Sosyal Bilimler Dergisi, 21(4), 1216-1229. DOI: 10.32709/ akusosbil.515847 
Katz, R., Callorda, F., \& Jung, J. (2020). Can digitization mitigate covid-19 damages? Evidence from developing countries [Web log post]. DOI: 10.2139/ssrn.3600829. Retrieved from http://www.teleadvs.com/wpcontent/uploads/SSRN-id3600829.pdf

Kemna, T. (2013). Dialogue, Twitter and new technology-based firms: The communication practice on a social medium (Master's Thesis, Stockholm University, Finland). Retrieved from http://www.diva-portal.org/smash/ get/diva2:629600/FULLTEXT01.pdf

Kent, M. L. (2017). Principles of dialogue and the history of dialogic theory in public relations. In: X. Chen (Ed.), Prospect of Public Relations Science (pp.105-129). Beijing, China: Peking University Press.

Kent, M. L., \& Taylor, M. (1998). Building dialogic relationships through the World Wide Web. Public Relations Review, 24(3), 321-334.

Kent, M. L., \& Taylor, M. (2002). Toward a dialogic theory of public relations. Public Relations Review, 28(1), 21-37.

Kim, D., Chun, H., Kwak, Y., \& Nam, Y. (2014a). The employment of dialogic principles in website, Facebook, and Twitter platforms of environmental nonprofit organizations. Social Science Computer Review, 32(5), 590-605. DOI: $10.1177 / 0894439314525752$

Kim, D., Kim, J.-H., \& Nam, Y. (2014b). How does industry use social networking sites? An analysis of corporate dialogic uses of Facebook, Twitter, Youtube, and Linkedin by industry type. Quality \& Quantity: International Journal of Methodology, 48(5), 2605-2614. DOI: 10.1007/s11135-013-9910-9

Krippendorf, K. (2004). Content analysis: An introduction to its methodology (2nd Edition). Thousand Oaks, California, USA: SAGE Publications.

Linvill, D. L., McGee, S. E., \& Hicks, L. K. (2012). Colleges' and universities' use of Twitter: A content analysis. Public Relations Review, 38, 636-638. DOI: 10.1016/j.pubrev.2012.05.010

McAllister-Spooner, S.M. (2009). Fulfilling the dialogic promise: a ten-year reflective survey on dialogic internet principles. Public Relations Review, 35(3), 320-322.

Men, L. R., Ji, Y. G., \& Chen, Z. F. (2017). Dialogues with entrepreneurs in China: How start-up companies cultivate relationships with strategic publics. Journal of Public Relations Research, 29(2-3), 90-113. DOI: $10.1080 / 1062726 X .2017 .1329736$

Men, L.R., Tsai, W.H.S., Chen, Z.F., \& Ji, Y.G. (2018). Social presence and digital dialogic communication: engagement lessons from top social CEOs. Journal of Public Relations Research, 30(3), 83-99.

Navarro-Ruiz, C., \& Humanes Humanes, M. L. (2012). Corporate blogging in Spanish companies. Design and application of a quality index (ICB). Comunicacion Y Sociedad, 27(2), 117-144.

Nielsen, R. K., Fletcher, R., Kalogeropoulos, A., \& Simon, F. (2020, October 27). Communications in the coronavirus crisis: Lessons for the second wave [Web log post]. Retrieved from https://reutersinstitute.politics.ox.ac.uk/ communications-coronavirus-crisis-lessons-second-wave

Oltarzhevskyi, D., Kliuchnykova, O., Sokolova, K., \& Tsymbalenko, Y. (2018). Communication pecularities of international and Ukrainian brands in social networks (facebook, twitter, instagram). Science and Education a New Dimension: Humanities and Social Sciences, 6(31), 69-73. 
Pang, A., Shin, W., Lew, Z., \& Walther, J. B. (2018). Building relationships through dialogic communication: organizations, stakeholders, and computer-mediated communication. Journal of Marketing Communications, 24(1), 68-82. DOI: 10.1080/13527266.2016.1269019

Paril, B. (2020, July 23). 2020 Trends: Covid impact on time spent with media [Web log post]. Received from https://www.digitalremedy.com/2020-trends-covid-impact-on-time-spent-with-media/

Rybalko, S., \& Seltzer, T. (2010). Dialogic communication in 140 characters or less: How fortune 500 companies engage stakeholders using Twitter. Public Relations Review, 36, 336-341. DOI: 10.1016/j.pubrev.2010.08.004

Sáez Martín, A., de Rosario, A. H., \& Caba Pérez, M. D. C. (2015) Using Twitter for dialogic communication: local government strategies in the European union. Local Government Studies, 41(3), 421-444. DOI: 10.1080/03003930.2014.991866

Saxton, G.D., \& Waters, R.D. (2014). What do stakeholders like on Facebook? Examining public reactions to nonprofit organizations' informational, promotional, and community-building messages. Journal of Public Relations Research, 26(3) 280-299.

Scott, W. (1955). Reliability of content analysis: The case of nominal scale coding. Public Opinion Quarterly, 19(3), 321-325. DOI: $10.1086 / 266577$

Seltzer, T., \& Mitrook, M. A. (2007). The dialogic potential of weblogs in relationship building. Public Relations Review, 33(2), 227-229. DOI: 10.1016/j.pubrev.2007.02.011

Shin, W., Pang, A. \& Kim, H. J. (2015). Building relationships through integrated online media: Global organizations' use of brand web sites, Facebook and Twitter. Journal of Business and Technical Communication, 29(2), 184-220. DOI: 10.1177/1050651914560569

Silahtaroğlu, G., Baykal, E., \& Canbolat, Z. N. (2020). Weekly emotional changes amidst covid-19: Turkish experience. Ekonomi, Işletme ve Maliye Araştırmaları Dergisi, 2(3), 280-304.

Silkü-Bilgilier, H. A., \& Kocaömer, C. (2020). Instagram in the context of dialogic communication: A content analysis for top performing brands on Instagram. Global Media Journal TR Edition, 10(20), 114-129.

Socialbakers.com. (2020). Social media trends report: The effects of covid-19 on marketing [Web log post]. Retrieved from https://www.socialbakers.com/blog/social-media-trends-report-q1-2020

Solis, B. (2011). Engage: The complete guide for brands and businesses to build, cultivate, and measure success in the new web. USA: Wiley.

Sundstorm, B., \& Levenshus, A. B. (2015). The art of engagement: dialogic strategies on Twitter. Journal of Communication Management, 21(1), 17-33. DOI: 10.1108/JCOM-07-2015-0057

Taylor, M., \& Kent, M. L. (2014). Dialogic engagement: clarifying foundational concepts. Journal of Public Relations Research, 26(5), 384-398.

Taylor, M., Kent, M. L., \&White, W. J. (2001). How activist organizations are using the Internet to build relationships. Public Relations Review, 27(3), 263-284. DOI:10.1016/S0363-8111(01)00086-8

Sanayi ve Teknoloji Bakanlığı. (2020, June). Teknoloji Geliştirme Bölgeleri: Genel bilgiler [Web log post]. Retrieved from https://www.sanayi.gov.tr/istatistikler/istatistiki-bilgiler.

Türkeli, S., \& Boyacı, A. R. (2019). Girişimci davranışlarının başlangıç aşamasındaki girişimlere etkisi: Türkiye Teknoparkları örneği. Girişimcilik ve İnovasyon Yönetimi Dergisi, 8(2), 21-38. 
Uluslararası Dijital Medya ve İletişim Derneği. (2020, November 2020). Dijital medya alışkanlıkları ve pandemi araştırması [Web log post]. Retrieved from https://www.udm.org.tr/post/dijital-medya-al\%C4\%B1\%C5\%9F kanl\%C4\%B1 klar\%C4\%B1-ve-pandemi-ara\%C5\%9Ft\%C4\%B1rmas\%C4\%B1

Wang, Y., \& Yang, Y. (2020). Dialogic communication on social media: How organizations use twitter to build dialogic relationships with their publics. Computers in Human Behavior, 104, 1-8. DOI: 10.1016/j. chb.2019.106183

We Are Social, \& Hootsuite (2020). Digital 2020: Turkey [Web log post]. Retrieved from https://datareportal.com/ reports/digital-2020-turkey

Wikipedia. (2020). Timeline of the covid-19 pandemic in Turkey [Web log post]. Retrieved from https://en. wikipedia.org/wiki/Timeline_of_the_Covid-19_pandemic_in_Turkey

Wold, S. (2020, September 16). Covid-19 is changing how, why and how much we're using social media [Web log post]. Retrieved from https://www.digitalcommerce360.com/2020/09/16/covid-19-is-changing-how-whyand-how-much-were-using-social-media/

Yağmurlu, A. (2013). Diyalojik iletişim çerçevesinden Ankara büyükşehir belediyesi sosyal medya uygulamaları. Selçuk Iletişim, 8(1), 95-115.

Yıldırım, A., \& Şimşek, H. (2018). Sosyal bilimlerde nitel araştırma yöntemleri (1 $1^{\text {th }}$ Ed.). Ankara, Turkey: Seçkin.

Yue, C. A., Thelen, P., Robinson, K., \& Men, L. J. (2019). How do CEOs communicate on Twitter? A comparative study between fortune 200 companies and top startup companies. Corporate Communications: An International Journal, 24(3), 532-552. DOI: 10.1108/CCIJ-03-2019-0031 


\section{TABLES AND FIGURES}

Table 1: Code Sheet

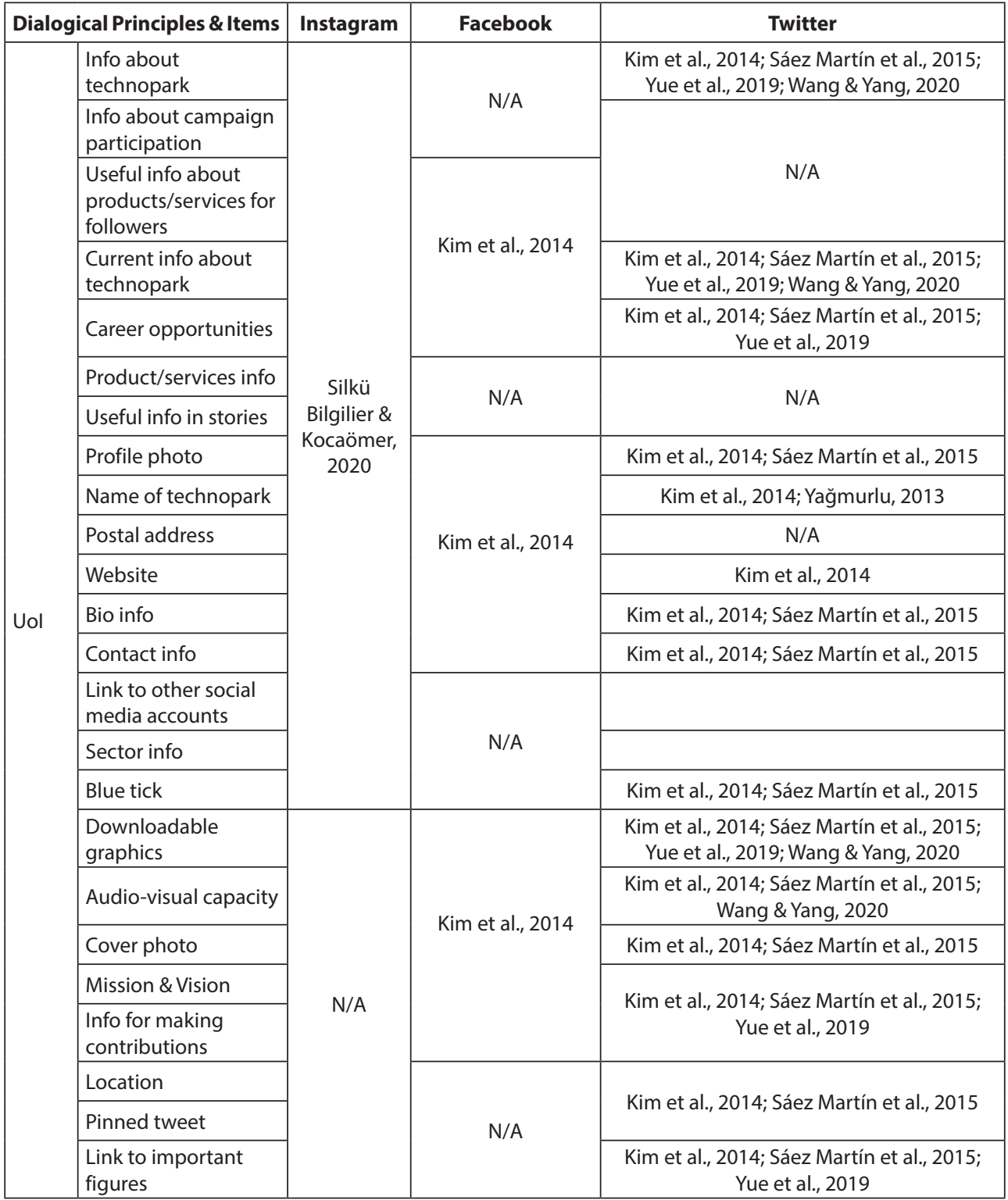




\begin{tabular}{|c|c|c|c|c|}
\hline \multirow{13}{*}{$\mathrm{CoV}$} & $\begin{array}{l}\text { Content from post to } \\
\text { story }\end{array}$ & \multirow{10}{*}{$\begin{array}{c}\text { Silkü } \\
\text { Bilgilier \& } \\
\text { Kocaömer, } \\
2020\end{array}$} & \multirow{5}{*}{$\mathrm{N} / \mathrm{A}$} & \multirow{5}{*}{$\mathrm{N} / \mathrm{A}$} \\
\hline & Photo in posts & & & \\
\hline & Video in posts & & & \\
\hline & Photo in stories & & & \\
\hline & Video in stories & & & \\
\hline & $\begin{array}{l}\text { Link to other social } \\
\text { media accounts }\end{array}$ & & & $\begin{array}{c}\text { Kim et al., 2014; Sáez Martín et al., 2015; } \\
\text { Yue et al., } 2019\end{array}$ \\
\hline & Staying up-to-date & & KIm et al., 2014 & Kim et al., 2014; Sáez Martín et al., 2015 \\
\hline & Link to website & & & $\begin{array}{l}\text { Kim et al., 2014; Sáez Martín et al., 2015; } \\
\text { Yue et al., 2019; Wang \& Yang, } 2020\end{array}$ \\
\hline & Highlights & & & \\
\hline & $\begin{array}{l}\text { Mentioning \& } \\
\text { Tagging its own } \\
\text { account }\end{array}$ & & $N / A$ & \\
\hline & Music feature & Oriainally & & \\
\hline & IGTV & added in & & \\
\hline & Boomerang & this $s$ & & \\
\hline
\end{tabular}




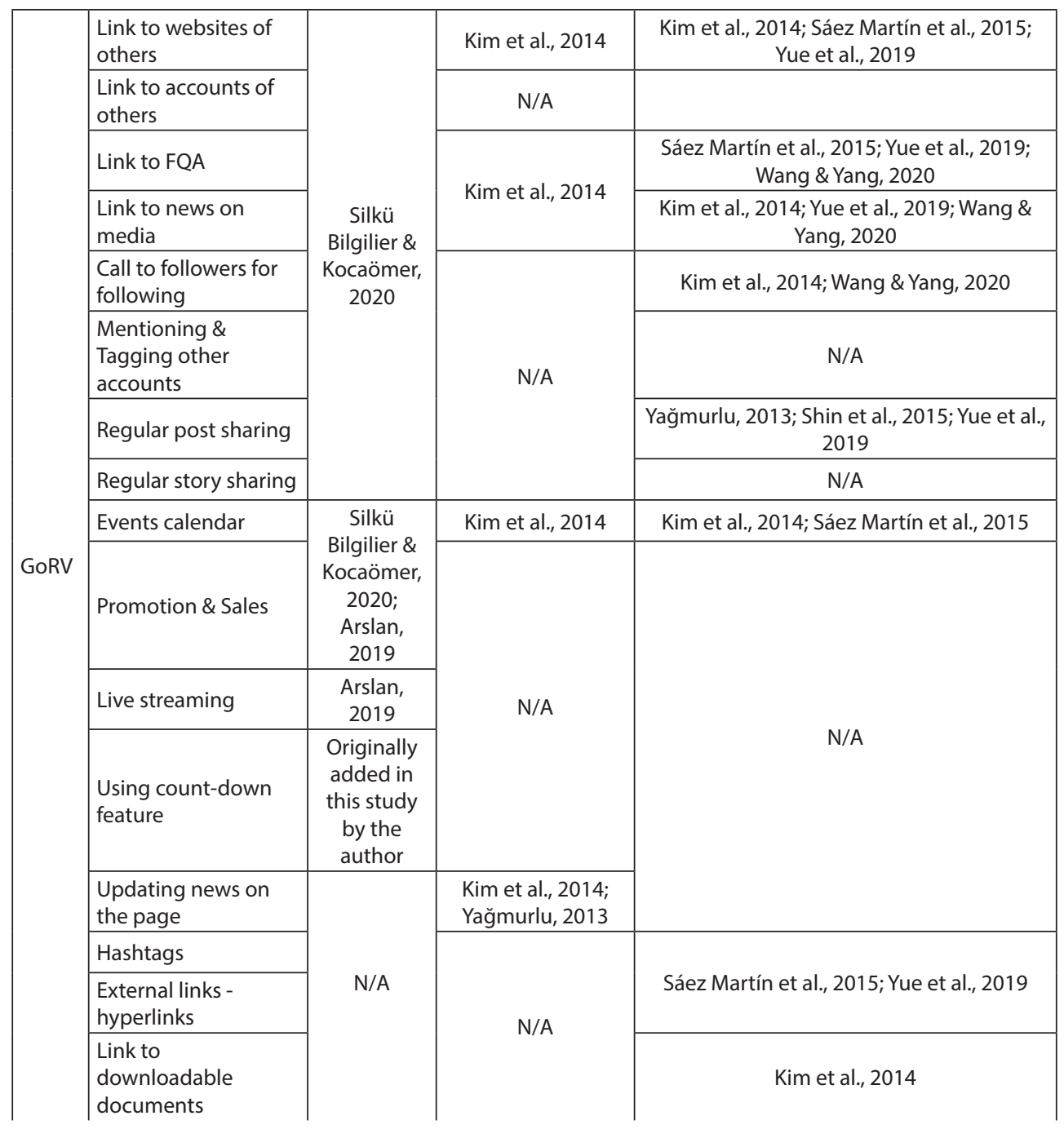




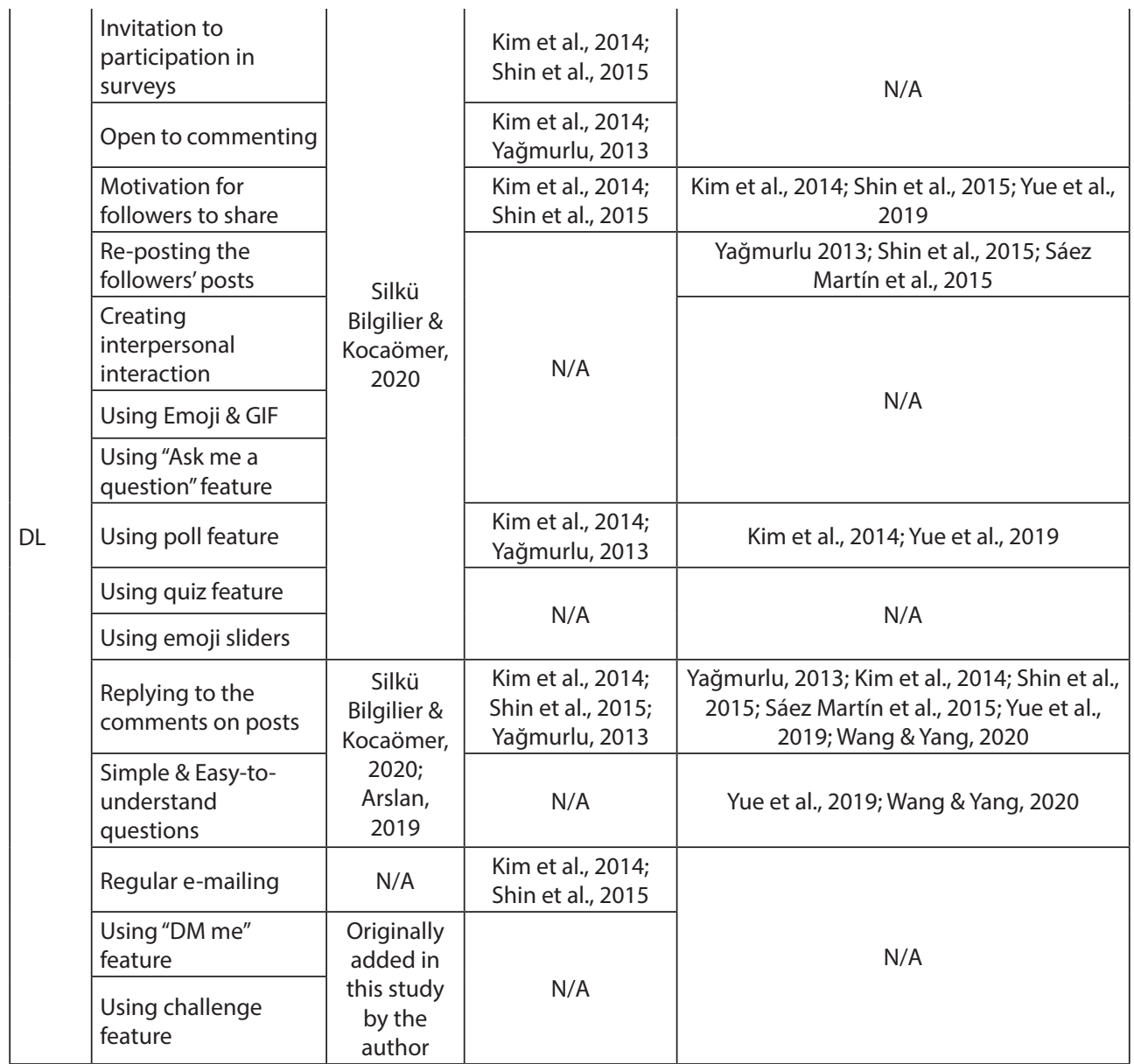

Uol: Use of Information

CoV: Conservation of Visitors

GoRV: Generation of Return Visits

DL: Dialogic Loop 
Figure 1: Quality indexes of social media platforms

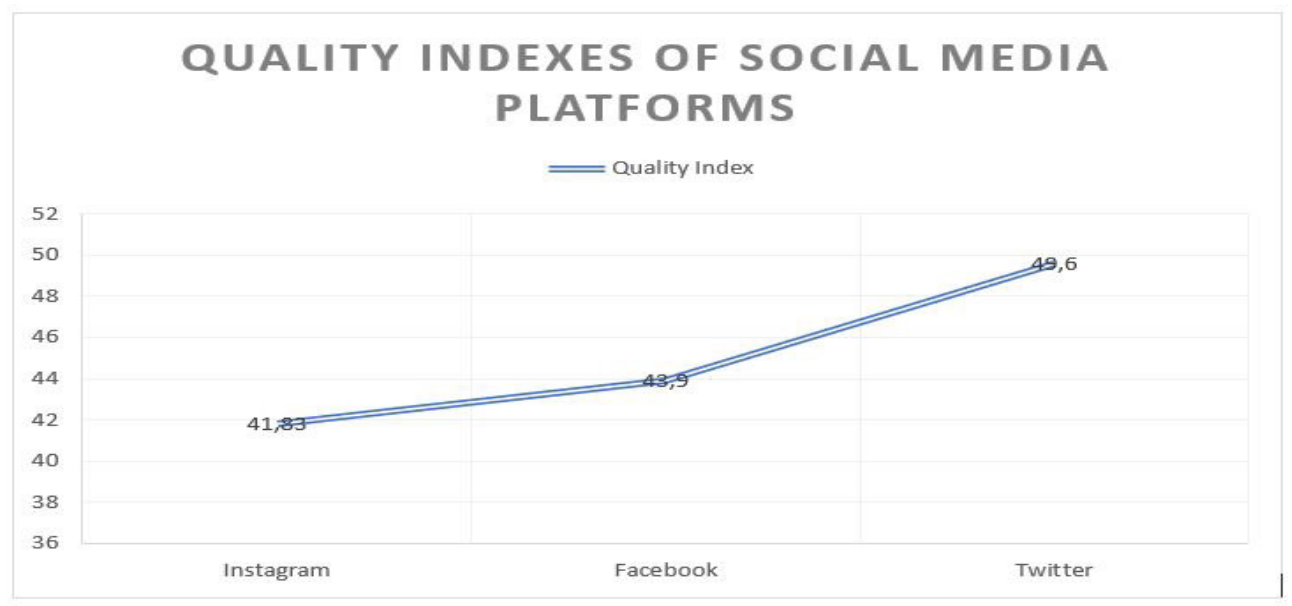

Figure 2: Quality indexes of social media platforms for each dialogic communication principle
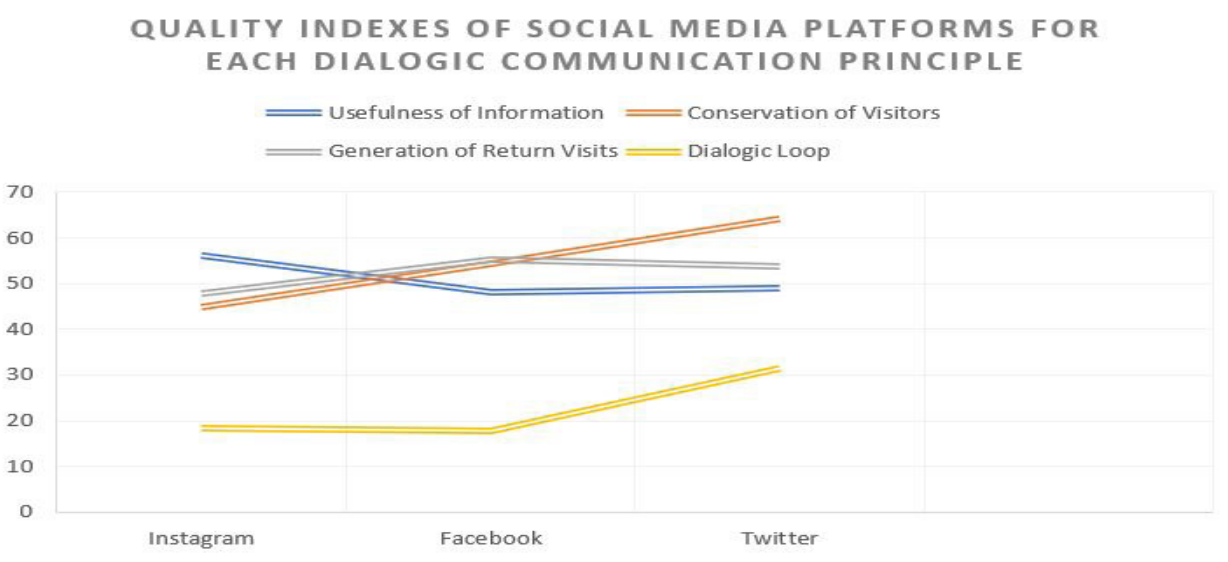